\title{
The Impact of National Labour and Social Law on the Law of the European Community
}

\author{
Niklas BRUUN
}

\section{Introduction}

There are two main channels through which national law can have an impact on the law of the European Community. The first is through legislation adopted by the Community institutions (regulations, directives, decisions etc.). The second is through the Court practice of the European Court of Justice (ECJ). I will comment on both.

I start with a simple distinction between three different types of EC law. This is followed by a discussion in the light of some examples of how national labour and social law influences the law of the European Community.

\section{Different types or categories of EC labour and social law}

- National labour laws harmonised through EC Directives or other instruments: The extensive EC regulation on health and safety forms one example of such harmonization. During such a legislative process of harmonization it is always possible that one or another country forms a model for the EC legislator, although in practice EC law usually is designed as a compromise between different national models.

- Regulation of the labour or social law aspects of cross-border or genuinely transnational phenomena involving labour in the internal market: European Works Councils, European Companies (SE), posting of workers, co-ordination of social security for workers who have been working in different Member States, etc.. Here the specific transnational feature of the regulation indicates that it cannot as such directly copy any national regulation.

- Indirect "regulation" is the third type of regulatory measures on EC level that have an impact on labour and social law: a strong internal market legal regime may restrict national labour and social law rights or practices; examples include competition law vs. collective agreements, economic rights to free movement vs. the right to collective bargaining and the right to resort to collective action, etc. Another kind of such indirect restriction is the prohibition of a trade union representative on a listed company's board of directors to discuss issues concerning 
the restructuring of the company with trade union colleagues, due to Directive 89/592/EEC on insider dealing (see ECJ Case C-384/02).

\section{The European model and structural differences in the legal systems of the Member States?}

National industrial relations and labour law systems in different Member States vary to a large extent. Variations can be traced on a structural level. This reflects the basic conceptual structure of this particular field of law.

Relevant distinctions include:

- private law/ public law,

- public sector employees/private sector employees,

- the definition of an employment relationship, etc.

There are significant differences between individual Member States. For example, these differences could result in different perceptions of whether working time regulation should be regarded as falling under the legislative competence of the former 118A of the Treaty. This stated that:

"Member States shall pay particular attention to encouraging improvements, especially in the working environment, as regards the health and safety of workers, and shall set as their objective the harmonization of conditions in this area, while maintaining the improvements made".

When the UK tried to nullify the Working Time Directive (93/104/EC, later consolidated as 2003/88/EC), the ECJ could have engaged in a lengthy analysis of the public law features of health and safety regulation in many Member States, in contrast to private law features of the regulation of working time. Instead, the Court adopted a very pragmatic approach. It emphasised that the powers given to the Community legislator should be given a broad interpretation covering "a state of complete physical, mental and social well-being" in accordance with the preamble to the Constitution of the World Health Organisation, to which all Member States belong (see ECJ Case C-84/94).

Structural differences also relate to the role and powers of the social partners at national level to bargain on issues that might be regulated by law.

The tradition of so-called "quasi-dispositive clauses" in Nordic labour legislation is well known. It has had a clear structural impact on EU law, both on the Treaty level (Article 139.2) and in several Directives. For instance, in the Directive on Working Time, Article 18:

"Derogations may be made from Articles 3, 4, 5, 8 and 16 by means of collective agreement or agreements concluded between the two sides of industry at national or regional level or....". 
Originally these kinds of provisions were called "Christophersen clauses" after the Danish European Commissioner for Economic and Financial Affairs (1985-1995), Henning Christophersen, who was a strong proponent of them.

General principles of labour or social law can seldom be related to one Member State only. Many academics were therefore somewhat surprised when the prohibition of age discrimination was declared to be a general principle of EU law in the Mangold decision (ECJ Case C-144/04). In fact, that seems to relate more to EU law than to specific national legislation. The creator of such legal principles is the ECJ; the Court has taken on an active role in this respect.

\section{Evolutionary features of EU labour law}

The evolution of EC law occurs through an interaction between Community legislation and court practice and between national and EU law. National law certainly has an impact. The internal market consists of national states and is therefore both national and European at the same time.

At least three types of legal evolution can be traced as standing behind the legal instruments of EC law.

First, there is the relatively rare situation where the EU institutions take the lead in regulating a specifically new and more or less unregulated area (in the Member States). To some extent, the EC regulation of discrimination (first, discrimination based on nationality, then sex discrimination, and later a long list of grounds) reveals such features.

Second, there is the normal situation where most Member States have an established legal tradition and regulations concerning a specific issue, which then becomes the object of a harmonisation effort at EC level.

Third, there is the situation where one or more Member States succeed in exporting their regulatory model, which becomes harmonized to apply to all Member States.

A normal legislative situation in labour law may involve a substantial number of Directives (on collective redundancies, transfer of undertakings, insolvency, working time, work environment, part-time work and fix-termed work, just to mention a few). Each Member State had its own national regulation of the field as a starting point. This will normally be regarded by each state as a reasonable basis for harmonization. Each state will try to convince the others that this is the best way to proceed. The negotiations in the Council become a process for adaptation to different models and finding workable compromises.

A more rare situation occurs when one country succeeds in exporting its legislation to other countries. When the EC adopted Directive 91/533/EEC on an employer's obligation to inform employees of the conditions applicable to the contract or employment 
relationship, it imported a legislative innovation from Britain, adopted in the Contracts of Employment Act in 1963. ${ }^{1}$

\section{Cross-border or transnational issues}

The harmonisation of national law becomes especially complicated when concerned with specific internal market issues that create special problems to be solved at EU level. One example is that of multinational companies and workers' representation: this has been difficult to solve, for instance, in relation to the European Company (SE) Regulation.

The process of adopting the Posted Workers Directive (96/71) ${ }^{2}$ (later PWD) illustrates how interaction between national and EU law occurs on several levels. I describe first its main contents, followed by some examples as to the interaction of national and EU law in the legislative process leading to the PWD.

The main purpose of the PWD is to impose the nucleus or "hard core" of labour laws on labour relations for cross-border posted workers. The Directive applies to undertakings established in a Member State which, in the framework of transnational provisions of services, post workers to the territory of another Member State. A "posted worker" according to the Directive (Article 2) is a worker who for a limited period carries out work in the territory of a Member State other than the State in which he normally works. This nucleus part of labour law covers above all wages and paid holiday provisions, safety and health measures, conditions for hiring-out of workers etc., as defined by Article 3 PWD. The PWD includes (Article 3(10)) the option to impose the wages and other nucleus provisions in host state collective agreements also in sectors other than construction. This imposition of host state wages and other nucleus provisions applies in construction sector always from the first day onwards whereas in initial assembly and/or installation of goods (outside construction sector) the home state wages and holiday provisions apply if the period of posting does not exceed eight days (Article $3(2)$ ). For small works and always by means of a representative collective agreement a threshold period of up to one month for the application of the host state conditions can be set up, but these options have obviously not been used at all.

The PWD regulates issues that are closely related to fundamental principles of EU law. The legal structure created by the PWD (in a nutshell: imposition of the host state conditions as a minimum) is akin to the equal treatment principle inherent in the free

1 See more in detail, Kenner, Industrial Law Journal 1999, 205-231. Kenner writes: "Remarkably, the Employee Information (Contract or Employment Relationship) Directive represents, with important adaptations, a rare example of an export of labour law from Britain to the Community..." (p. 206).

2 Directive 96/71/EC of the European Parliament and of the Council of 16 December 1996 concerning the posting of workers in the framework of the provision of services. 
movement of workers (Article $39 \mathrm{EC}$ and Regulation 1612/68), which is one of the fundaments of the whole internal market and a reflection of equal treatment regardless of nationality, one of the leading principles of the Community (Article 12 EC). Secondly, it shows a certain elasticity of EU law in the sense that it was adopted within the framework of the services provisions of the EC Treaty although the material provisions are largely of labour law, normally subject to the Social Policy Title of the Treaty. Thirdly, the PWD represents an amalgamation of the interests of management and labour, or, as Recital 5 puts it: "Whereas any such promotion of the transnational provision of services requires a climate of fair competition and measures guaranteeing respect for the rights of workers". Thus, from the point of view of EU law the PWD seeks to create a competitive environment of neutrality in relation to working conditions.

This neutrality becomes, however, more nuanced and closer to the labour market reality if seen in its final national context. Thus, domestic employers get directly by virtue of EU law the guarantee that foreign competitors are not allowed to use posted manpower with wages etc. lower than those binding them as national erga omnes provisions. Domestic workers and their organisations get a similar guarantee which, however, does not mean to endorse their wages if these are higher than those in the 'books', i.e. in the collective agreement concerned. Hence, the influx of manpower, for instance in the construction sector of Germany since early 1990s, with wages strictly equal to the minima in the collective agreement concerned, creates pressure against actual domestic wages above that level and the PWD stops this pressure on the level of the collective agreement concerned. Accordingly, while it is impossible to protect these higher wages by national law, it is equally impossible in terms of EU law.

In the legislative process leading up to the PWD, the first landmark was the judgment Seco of 1982 in which the ECJ as an obiter dictum confirmed the right of Member States to extend their laws and collective agreements to cover also posted workers. ${ }^{3}$ This happened contrary to the express opinion of the Advocate General who found the compulsory tolerance of low-wage competition to be one of the fundamental features of the Common Market. The obiter dictum was repeated by the ECJ in Rush Portuguesa 4 in 1990. That case concerned a Portuguese company that posted its personnel to railway works into France. This episode together with the obiter dictum of the ECJ was the vehicle for France when it adopted a new posting law in 1994 (then L342-3 of the Code du travail). On the European scene, this also gave a strong push towards establishing a qualified majority behind a PWD with no obligatory threshold period in the application of host state terms and conditions. Adopting a national posting law in Germany in February 1996 (Arbeitnehmer-Entsendegesetz, AEntG) had a similar effect on the discus-

3 Joined Cases 62/81 and 63/81 Seco and Desquenne \& Giral v EVI [1982] ECR 223, paragraph 14.

4 Case C-113/89 Rush Portuguesa Ld $v$ v Office national d'immigration [1990] ECR I-1417, paragraph 18. 
sion among legislators in the EC Council. 5 Also the German act was prepared on the basis of Rush Portuguesa, but in a climate of already rampant wage dumping by foreign contractors active in Germany. On the other hand, the PWD under preparation also had a certain legitimizing effect on national legislative debates because the Directive was to turn the extension of host state terms and conditions from an option into an obligation of the Member States.

However, the PWD did not establish any special wage category/ies applicable to posted workers as did the AEntG, but left the definition of the minimum wages concerned up to national law and/or practice (Article 3(1), second subparagraph). Without doubt, however, the PWD and European law in general terms allow the special lower wage categories applied to posted workers under the AEntG because they are applied also to domestic non-organized workers and employers.

Leaving the definition of the minimum wage up to the Member States corresponds to the typical limits of European legislation, directives in particular: the EU establishes premises, principles and goals, whereas the Member States provide the means and details to implement the European obligations. By basing its main obligation, i.e. the application of the host state pay provisions, essentially on national law, the PWD is linking EU labour law with national labour law in the EU.

Finally, the EC Treaty has an effect also on the interaction of European and national law by requiring that the Member States, in implementing the PWD, respect also the obligations stemming directly from the services provisions of the Treaty (Articles 49 and $50 \mathrm{EC}) .{ }^{6}$ In practice, the requirement that the national measures must be proportionate, seems to work (only) as a safety valve against social protectionism, ${ }^{7}$ which corresponds to the PWD's nature as a minimum directive (Article 3(7)).

To sum up, the process of adopting the Posting of Workers Directive illustrates how interaction between Member States and EU institutions occurs on several levels. The ECJ gave its Rush Portuguesa judgment (Case C-113/89) in 1990, France adopted legislation in 1994 and Germany in 1996, just before the Directive 96/71/EC was adopted in 1996. In order to meet Danish and Swedish concerns, the Directive contains a Christophersen clause (Article 3.8) and it explicitly stipulates that it does not cover industrial action (Preamble, Recital 22).

5 The contents of the PWD became fixed by the common position of the Social Council of 29 March 1996.

6 Case C-60/03 Wolff\&Müller [2004] ECR I-9553, paragraphs 30 to 35; identically in case C-490/04 Commission v Germany, judgment of 18.7.2007, nyr, e.g. paragraph 19.

7 See case C-341/02 Commission v Germany [2005] ECR I-2733, where the proportionality requirement in paragraph 24 was de facto elaborated (i.e. alleviated) by the criterion of normal cases ('it is entirely normal...') in paragraph 40, operative in the final assessment of the national implementing measure. Hence, what is normal is also proportionate. In broader terms, Wolff\&Müller, paragraph 44, and C-490/04 Commission v Germany, paragraph 46, refer to (social) protection of workers as the yardstick of proportionality assessment. 


\section{VI. “Indirect regulation": Competition law and collective agreements}

What I described as indirect regulation by European law has a crucial impact on labour law, but is mainly accomplished by the ECJ. A good example of this situation was the ECJ case Albany whereof I give a summary explanation. Thus, the judgment of 21 September 1999 in the joined cases Albany, Brentjens and Drijvende Bokken ${ }^{8}$ filled in a gap of more than forty years in the EC Treaty by defining the relationship between collective agreements and competition rules, notably Article 81 EC. Each of the three cases dealt with a single sectoral pension fund in the Netherlands - each running a supplementary occupational pension scheme established by a sectoral collective agreement that had been declared binding erga omnes. This meant that every worker in the three sectors concerned had to be affiliated to the sector's fund unless the fund itself granted an exemption. The funds operated on the basis of sector-wide solidarity, for instance by levying flat rate contributions and by linking the benefits to an average wage. ${ }^{9}$ The companies concerned wanted to dispense with the compulsory affiliation by arranging similar or better pension benefits, as they argued, for a lower price outside the fund. They invoked Article 81 (ex 85) EC on competition that notoriously is a fundamental provision for the functioning of the internal market and is also directly effective EU law.

The judgment was based upon a double assessment: first, on the status in principle of the negotiating social partners in relation to competition rules, followed by a positioning of the resulting collective agreements in the same relation.

Thus, the ECJ reasoned that restrictions of competition are inherent in collective agreements but continued, with a reasoning on the level of social values, that "the social policy objectives pursued by such agreements would be seriously undermined if management and labour were subject to Article [81(1)] of the Treaty when seeking jointly to adopt measures to improve conditions of work and employment". ${ }^{10}$ This exclusion was contrary to the opinion of Advocate General who resumed that there is between the negotiating employers an implied agreement in the sense of Article $81 \mathrm{EC}^{11}$ - a reasoned statement that, however, disregarded the most essential legal ingredient of a collective agreement, namely the contractual relationship between the social partners (not any stipulations inside a party).

8 See cases C-67/96 Albany [1999] ECR I-5751; C-115 to 117/97 Brentjens [1999] ECR I-6025; and C-219/97 Drijvende Bokken [1999] ECR I-6121. For an overall analysis of the judgment, see Bruun Niklas \& Hellsten Jari (eds.), Collective Agreement and Competition Law in the EU, DJØF Copenhagen 2001 (Bruun \& Hellsten). As to later doctrinal discussion, see Hellsten Jari, On the Social Dimension in the Context of EC Competition Law, Ministry of Labour, Publication 323/2006; http://www.mol.fi/mol/fi/99_pdf/fi/06_tyoministerio/06_julkaisut/06_tutkimus/tpt323.pdf.

9 See paragraphs 75 and 108 of Albany.

10 Paragraph 59 of Albany.

11 Paragraphs 237-244 of the opinion of 28.1.1999. 
The ECJ confirmed, on the basis of an effective and consistent interpretation of the EC Treaty as a whole, that collective agreements by virtue of their nature and purpose did not fall within the ambit of Article 81 EC. 12 "Nature" in this case meant that the agreement was made in the form of a collective agreement and resulted from negotiations of representative social partners. 13 "Purpose" meant that the scheme concerned sought generally to guarantee a certain level of pension for all workers in the sector and therefore contributed directly to improving one of their working conditions, namely their remuneration. ${ }^{14}$ Thus, while the judgment unequivocally established the immunity of collective agreements in relation to competition rules (where the nature and purpose test finally works as a safety valve against masked distortion of competition), it left open whether the limits of such immunity are defined by 'social policy objectives' or 'working conditions'. 15

The grounds in the reasoning of the ECJ16 were anchored even in Articles 2 and 3 EC and referred also to Article 118b of the old EC Treaty (now Article 139 EC) on contractual relationships between social partners, as well as to the social dialogue provisions in the 1992 Maastricht Social Policy Agreement. Notable also is that the immunity of collective agreements resulted from an effective and consistent interpretation of the EC Treaty as a whole, which implies, given alone the nature and purpose test applied, that no traditional proportionality assessment was performed in the application of immunity. Albany further creates the basis of immunity also for European and companylevel collective agreements. From today's perspective, i.e. after the adoption of the EU Charter of Fundamental Rights and certainly after its introduction as a valid source in interpreting EU la 17 as well as in light of the forthcoming Reform Treaty, the grounds of the ECJ in Albany are precisely reinforced by the fundamental rights argument (which the ECJ was able to disregard in 1999).

\section{The relevance of the Albany case for industrial action}

The outcome of the Albany case was a good example of so called indirect regulation of the limits in which collective agreements can operate. A more restricted approach

12 Paragraph 60 of Albany.

13 Paragraph 62.

14 Paragraph 63.

15 Further case-law, thus cases C-180-184/98 Pavlov [2000] ECR I-6451 and C-222/98 van der Woude [2000] ECR I-7111, has not decided this issue. A decision thereon would obviously require a case that falls inside 'social policy objectives' but outside 'working conditions'.

16 Paragraphs 54 to 58 of Albany.

17 Case C-540/03 Parliament $v$ Council [2006] ECR I-5769, paragraph 38; case C-432/05 Unibet, judgment of 13.3.2007, nyr, paragraph 37; and case C-303/05 Advocaten voor de Wereld, judgment of 3.5.2007, nyr, paragraph 46 . 
would have created serious problems for collective agreements in several Member States, and the approach of the ECJ was well founded. The ECJ adopted a clear approach: creating an immunity for certain typical terms in collective agreements regulating "conditions of work and employment" or having "social policy objectives".

This is very much a Nordic approach. In all the Nordic countries, the legislator long ago defined a certain area for collective bargaining in which competition law does not apply. The advantage of such an approach is that there is no need for balancing acts or "proportionality" reasoning in cases that are of a normal type. 18

The approach taken by the two Advocates General, Mengozzi and Maduro, in the pending cases Laval (Case C-341/05) and Viking (C- 438/05) takes another route which raises some concern.

Again the issue at stake is whether the Treaty provisions on economic freedoms (free movement of services, right to free establishment) restrict the right or freedom to undertake national or transnational industrial action. Indirectly, the answer to such a question will have an impact on national industrial relations and how trade unions can defend the interests of their members.

Indeed, the most important reference question in the collective action case Viking 19 asks exactly about the interpretation of Albany by analogy as regards the relationship of rules on freedom of establishment and services on the one hand, and on collective action on the other.

Both Advocates General recognize the right to take collective action as a fundamental right in EU law. In that respect they clearly build on the national constitutional traditions in most Member States (which again are based on such relevant international treaties as ILO Conventions 87 and 98 and the European Social Charter), and also on the developments in the European Union where Article 28 of the Fundamental Rights Charter prescribes that "[w]orkers or their respective organisations, have, in accordance with Union law and national laws and practices, the right to negotiate and conclude collective agreements at the appropriate levels and, in the cases of conflicts of interest, to take collective action to defend their interests, including strike action".

However, the Advocates General appear to want to introduce a kind of "proportionality" test to balance between free movement of services and freedom of establishment in the EU, on one hand, and the fundamental right to take collective industrial action, on the other. ${ }^{20}$ This means that they are abandoning the Albany approach. They do not seem to agree that, given that competition rules are an elementary part of the foundations of the Community in the same way as the rules on free movement of services or free establishment, it is justified to regard the Albany immunity as a general principle

18 See Bruun \& Hellsten pp. 53.

19 Pending case C-438/05 International Transport Workers' Federation and Finnish Seamen's Union $v$ Viking Line.

20 Maduro does not explicitly use the word proportionality, but his reasoning contains similar elements. 
shaping the overall understanding of the developing relationship between economic and social factors in the EU.

The Advocates General apparently do not take into account that any immunity for industrial action should, even under the Albany approach, be limited to genuine action related to "conditions of work and employment" or legitimate "social policy objectives". Under such an approach it could be perfectly possible for the national courts to restrict industrial action with clearly discriminatory aims. If, say, a trade union takes action in order to keep certain nationalities or groups outside the labour market altogether, this would fall outside the ambit of immunity and be forbidden. Such an approach could also integrate a vision of social justice into the conception of free movement (free establishment) in EC law, which the Advocates General fail to do.

The proposed methods of conducting the proportionality balancing test remain rather unclear in the opinions presented by the Advocates General. For Mengozzi, the proportionality test seems to focus on the aim of the industrial action, although he also addresses the way it is carried out: 21

"I consider that... Directive 96/71 and Article 49 EC do not prevent trade unions from attempting, by means of collective action in the form of blockade and solidarity action, to compel a service provider of another Member State to subscribe to the rate of pay determined in accordance with a collective agreement which is applicable in practice to domestic undertakings in the same sector that are in a similar situation and was concluded in the first Member State, to whose territory workers of the other Member State are temporarily posted, provided that the collective action is motivated by public interest objectives, such as the protection of workers and the fight against social dumping, and is not carried out in a manner that is disproportionate to the attainment of those objectives."

For Maduro, the proportionality test seems to emphasize an evaluation of the effect of the industrial action. An effective coordinated collective action based on an obligation imposed on national unions to support collective action that has the effect of partitioning the labour market is in his view not proportional.

All in all the balancing tests proposed by the Advocates General seem to introduce completely new, unknown and vague balancing criteria, which are unknown in the practice of international treaties regulating the right or freedom of industrial action. These criteria apparently go much further in restricting the right to take collective action than do present national restrictions on this constitutional right.

The result - if their Opinions are followed - could lead to a constitutional dilemma from the point of view of national law. This is something that should be carefully anticipated by the ECJ. In particular, where the Court produces judgments that profoundly interfere with an area where European Union legislative competence is explicitly restricted, the Court should be cautious in introducing restrictions. The kind of restrictions proposed by the Advocates General reflect some lack of insight as to how labour law operates in practice. For instance, the possibility for a federation to impose an obligation on a member union, based on membership and internal rules, to take part in common

21 Opinion of Mengozzzi (Case C-341/05, 23 May 2007) p. 307. 
collective action forms a basic principle of freedom of association as it has evolved in ILO practice. If the paths proposed by the Advocates General are followed by the ECJ, we risk at least two things: First, the vague guidance on proportionality assessment will lead to highly divergent national assessments in different Member States. In the process, the interpretation of the impact of such important Treaty articles as Articles 43 and 49 will become completely different in various Member States. Second, the ECJ is at risk of opening the floodgates for future cases concerning industrial conflict that are brought before the Court in order to further develop and get clarification on the internal market restrictions on the right to industrial action.

The conclusion is that the ECJ in the pending cases will have to decide upon how to integrate the right to transnational industrial action into EC law. This process forms an illustrative example of how different national models "compete" as regards their influence on the formation of EC labour law. 


\title{
Slovenian Labour and Social Law in Relation to the EC Law
}

\author{
Barbara KRESAL
}

\section{Introduction}

In today's economy, which is becoming more and more globalized, labour and social law still remain mostly national. Even in the European Union (EU), the most advanced regional organisation in the world, the Community is not competent for issues like pay, freedom of association, strikes and other industrial action. Other important topics like social security, job security and workers participation are subject to the unanimity rule. ${ }^{1}$

However, within the EU it is constantly emphasised that sustainable economic growth goes hand in hand with social cohesion. »Existing international economic and social rules and structures are unbalanced at the global level. Global market governance has developed more quickly than global social governance. $\ll^{2}$ The European social model, based on flexicurity, aims at strengthening the social aspects of development strategies adequately. The EU is seen by many as an important international actor in preserving and developing further such a model, which tries to balance between economic and social interests and respects European social heritage as well. In this respect, the role of the Court of the European Communities (the European Court of Justice ECJ) may not be overlooked.

An important body of acquis communautaire has been developed in the field of labour and social law during the 50 years of European integration. There are many directives relating to labour relations and social security, addressing issues like prohibition of discrimination and the principle of equal treatment, collective dismissals, transfers of businesses and undertakings, protection of workers' claims in case of the employer's insolvency, protection of safety and health at work, etc. And the ECJ has issued many

1 Blanpain, R./Colluci, M. (2004): The Globalization of Labour Standards, Kluwer, The Hague, p. 15. Blanpain points out that there is no countervailing power, either regional or international, to transnational economic decision-making. And national states remain weak in this regard. Casale, for instance, speaks about »the progressive erosion of state sovereignty«. Global economic integration weakens government's intervention in macro-economic and social policies; states are competing to offer transnational economic actors the best tax, legislative and social conditions to attract investment. (Casale, G. (2005): Globalization, Labour Law and Industrial Relations - Some Reflections, In: Blanpain (ed.): Confronting Globalization, The Quest for a Social Agenda, Kluwer, The Hague, p.39-40).

2 EU Commission (2005): Promoting Core Labour Standards and Improving Social Governance in the Context of Globalization, In: Blanpain (ed.): Confronting Globalization, The Quest for a Social Agenda, Kluwer, The Hague, p. 55-56. 